\title{
PERTANGGUNGJAWABAN PIDANA RUMAH SAKIT TERHADAP TINDAK PIDANA PEMALSUAN JUMLAH TAGIHAN UANG KEPADA BADAN PENYELENGGARA JAMINAN SOSIAL (BPJS)
}

\author{
sonyaairinibatubara@unprimdn.ac.id \\ mazmursrumapea@unprimdn.ac.id \\ yusriando@unprimdn.ac.id
}

\author{
Departemen Hukum Pidana, Fakultas Hukum, Universitas Prima Indonesia \\ Jl. Sekip Simpang Sikambing, Medan, Sumatera Utara, 20112
}

\begin{abstract}
Hospital is an institution that provides comprehensive health services that are preventive, promotive, curative and rehabilitative for the general public as stipulated in Article 1 paragraph (3) of Law Number 44 Year 2009 concerning Hospitals, which says "Comprehensive health services including promotive health services, preventive, curative, and rehabilitative services In addition, hospitals are institutions that are capital, technology and human resource intensive, so that they have the potential to cause problems both internal and external.The hospital was previously considered a social institution that provides medical assistance to the public, but At present the position of the hospital has undergone a change, which has shaped a social institution into an institution in the form of a corporation established under the law that has rights and obligations as a legal entity that leads to a dominant profit - the search for health services. in the present, in the case of $\mathrm{k}$ In hospitals, patients file a doctor's case, especially criminal law, and never ask the hospital for responsibility for corporate crime that its establishment has a legal entity (rechts persoon). That the authors are interested in reviewing whether a hospital as a corporation can be held liable for criminal liability.

This study aims (1) To find out the sanctions imposed on hospitals for criminal acts of counterfeiting the amount of money bills to the Social Security Organizing Agency (BPJS) (2) To determine the responsibility of hospitals for criminal acts of counterfeiting the amount of money bills to the Social Security Administering Board (BPJS). The method used in this research is analytical descriptive using a normative juridical approach supported by an empirical juridical approach. The data used are (1) primary data in the form of interviews with Sari Mutiara Hospital, (2) secondary data through a literature study on various laws and regulations / books / journals to obtain expert opinions. The results of this study are expected to be published through (1) scientific articles in the Accredited National Journal and (2) teaching materials in Criminal Law courses at the Faculty of Law, University of Prima Indonesia. The results of this study indicate that hospitals are criminally responsible because hospitals as corporations are legal entities (rechts persoon) that have rights and obligations. Through this publication it is hoped that sanctions and accountability by hospitals for falsification of the amount of bills given to BPJS are clearer so that they do not incur losses in large costs that must be borne by the state.
\end{abstract}

Keywords: Criminal Liability, Hospital, Counterfeiting 


\section{Intisari}

Rumah sakit adalah lembaga yang menyediakan layanan kesehatan yang komprehensif di preventif, promotif, kuratif dan rehabilitatif untuk masyarakat pada umumnya diatur dalam Pasal 1 ayat (3) UU Nomor 44 Tahun 2009 Tentang Rumah Sakit, yang mengatakan "Kesehatan menyeluruh layanan layanan kesehatan yang termasuk promotif, preventif, kuratif , dan layanan rehabilitatif. Selain itu, rumah sakit adalah institusi yang padat modal, teknologi dan sumber daya manusia, sehingga berpotensi menimbulkan masalah baik internal dan eksternal. Rumah sakit sebelumnya dianggap sebagai lembaga sosial yang memberikan bantuan medis kepada publik, tetapi saat ini posisi rumah sakit telah mengalami perubahan, yang sudah berbentuk sebuah sosial lembaga menjadi sebuah institusi di bentuk dari sebuah korporasi yang didirikan di bawah hukum yang memiliki hak dan kewajiban sebagai badan hukum yang mengarah ke sebuah dominan keuntungan - pencarian kesehatan jasa . Masalah yang muncul di masa sekarang, dalam kasus kesalahan rumah sakit, pasien mengajukan perkara dokter, khususnya hukum pidana, dan tidak pernah menanyakan tanggungjawab rumah sakit terhadap kejahatan korporasi bahwa pendiriannya memiliki badan hukum (rechts persoon). Bahwa penulis tertarik untuk meninjau apakah rumah sakit sebagai sebuah korporasi dapat dimintakan pertanggungjawaban pidananya. Penelitian ini bertujuan (1) Untuk mengetahui sanksi yang diberikan kepada rumah sakit terhadap tindak pidana pemalsuan jumlah tagihan uang kepada Badan Penyelenggara Jaminan Sosial (BPJS) (2) Untuk mengetahui pertanggungjawaban pidana rumah sakit terhadap tindak pidana pemalsuan jumlah tagihan uang kepada Badan Penyelenggara Jaminan Sosial (BPJS). Metode yang digunakan dalam penelitian ini adalah deskriptif analitis dengan menggunakan pendekatan yuridis normatif yang didukung oleh pendekatan yuridis empiris. Data yang digunakan adalah (1) data primer berupa hasil wawancara terhadap Rumah Sakit Sari Mutiara, (2) data sekunder melalui studi pustaka terhadap berbagai peraturan perundangan serta buku/jurnal untuk memperoleh pendapat para ahli. Hasil penelitian ini diharapkan dapat dipublikasikan melalui (1) artikel ilmiah pada Jurnal Nasional Terakreditasi dan (2) bahan ajar pada mata kuliah Hukum Pidana di Fakultas Hukum Universitas Prima Indonesia. Dari hasil penelitian ini menunjukkan rumah sakit bertanggung jawab secara pidana karena rumah sakit sebagai korporasi merupakan badan hukum (rechts persoon) yang memiliki hak dan kewajiban. Melalui publikasi tersebut diharapkan agar sanksi dan pertanggunggjawaban oleh rumah sakit atas perbuatan pemalsuan jumlah tagihan yang diberikan kepada BPJS lebih jelas sehingga tidak menimbulkan kerugian beban biaya besar yang harus ditanggung oleh negara.

Kata kunci: Pertanggungjawaban Pidana, Rumah Sakit, Pemalsuan 


\section{PENDAHULUAN}

Rumah sakit berperan penting mewujudkan kesehatan masyarakat yang optimal, sehingga dituntut mampu mengelola kegiatannya dengan mengutamakan pada tanggung jawab profesionalnya. Rumah sakit dibagi berdasarkan pengelolaannya, dibagi menjadi rumah sakit publik dan rumah sakit privat. Rumah sakit publik dikelola oleh pemerintah, pemerintah daerah ataupun yang dikelola oleh Badan hukum yang bersifat nirbala, sehingga rumah sakit publik dapat disebut sebagai rumah sakit non-komersial. Rumah sakit pemerintah diselenggarakan berdasarkan pengelolaan Badan Layanan Umum atau Badan Layanan Daerah. Rumah sakit yang dikelola oleh pemerintah tidak dapat dialihkan menjadi rumah sakit privat (Pasal 20 UU Rumah Sakit). Rumah sakit privat (swasta) dikelola oleh badan hukum dengan tujuan profit yang berbentuk Perseroan Terbatas atau Persero (Pasal 21 UU Rumah Sakit), sehingga rumah sakit privat dapat sebagai rumah sakit komersial.

Perkembangan usaha di bidang asuransi kesehatan baik yang komersial maupun asuransi kesehatan sosial di Indonesia mengalami perkembangan yang cukup pesat. Perkembangan ini terjadi terutama dalam asuransi kesehatan sosial setelah diundangkannya Undang-Undang Nomor 24 Tahun 2011 tentang Badan Penyelenggara Jaminan
Sosial (BPJS) di Indonesia. Di dalam undang-undang ini ditentukan bahwa BPJS bidang kesehatan diselenggarakan dengan sistem asuransi kesehatan sosial yang mulai diberlakukan mulai tanggal 1 Januari 2014.

Di dalam program asuransi kesehatan komersial maupun sosial terdapat hubungan triparteit yaitu antara Perusahaan Asuransi/BPJS sebagai badan penyelenggara (Penanggung), Pengguna manfaat sebagai peserta (Tertanggung) dan Pemberi Pelayanan Kesehatan (PPK). Dalam pelaksanaan klaim asuransi sosial kesehatan tersebut sering terjadi kecurangan (fraud), hal ini pernah terjadi dalam program ASKESKIN dengan membengkaknya jumlah dana yang harus dibayarkan PT. Askes sebagai Penanggung ke Pemberi Pelayanan Kesehatan (PPK). Pada saat itu berbagai media sering ditulis keluhan PPK yang merasa haknya belum dibayar oleh PT. Askes, di sisi lain PT. Askes sebagai pihak pengelola dana merasa kewalahan membayar tagihan klaim yang ternyata jumlahnya melebihi kuota anggaran yang disediakan pemerintah, dan di sisi berikutnya ternyata pemerintah mengalami kesulitan mencari dana untuk menutupi kekurangan tersebut.

Berbagai bentuk kecurangan $(\text { fraud })^{1}$ serupa dapat ditemukan dalam

1 Kanon Armiyanto, makalah Seminar Sehari "Kecurangan (fraud) Dalam Jaminan/Asuransi Kesehatan" diselenggarakan oleh PAMJAKI (perhimpunan Ahli Manajemen Jaminan dan Asuransi Kesehatan Indonesia) di Hotel Bumi Karsa, pada tanggal 13 Desember 2007. 
klaim asuransi sosial kesehatan, yang dapat dilakukan oleh individu ataupun kelompok maupun oleh pemberi pelayanan kesehatan pada tingkat pertama maupun rumah sakit sebagai penerima rujukan. Bentuk kecurangan ini dapat terjadi karena ketidak pahaman masyarakat pengguna pelayanan kesehatan ataupun dilakukan oleh PPK karena biaya pengobatan ditanggung oleh penanggung.

Secara teoritis terdapat beberapa faktor penyebab yang memungkinkan terjadinya fraud, antara lain ${ }^{2}$ :

a. Kebutuhan (need) dimana situasi pemegang polis dan/atau tertanggung sebelum terjadinya kerugian sedang mengalami kesulitan keuangan.

b. Kesempatan (opportunity), misalnya sebab kerugian yang tidak dapat ditelusuri atau ada celah hukum yang dapat dimanfaatkan oleh pemegang polis dan/atau tertanggung untuk mengajukan klaim fiktif.

c. Keserakahan (greed) dapat tercermin dari rasionalisasi/sikap yang memandang tindakan fraud sebagai suatu pembenaran atau justifikasi dan sesuai dengan kode etik.

Berdasarkan latar belakang yang telah diuraikan di atas maka yang akan menjadi pokok permasalahan pada penelitian ini adalah (1) Bagaimana aspek hukum pidana dalam asuransi berdasarkan peraturan hukum di Indonesia?

Bagaimana pertanggungjawaban pidana rumah sakit terhadap pemalsuan jumlah tagihan uang kepada BPJS?

\section{Tujuan dan Manfaat Penelitian}

\section{a. Tujuan Penelitian}

Tujuan penelitian ini adalah (1) Untuk mengetahui aspek hukum pidana dalam asuransi berdasarkan peraturan hukum di Indonesia dan (2) Untuk mengetahui pertanggungjawaban pidana rumah sakit terhadap pemalsuan jumlah tagihan uang kepada BPJS.

\section{b. Manfaat Penelitian}

Publikasi penelitian ini diharapkan dapat dilakukan (1) artikel ilmiah pada Jurnal Nasional terakreditasi dan (2) bahan ajar pada mata kuliah Hukum Pidana di Fakultas Hukum Universitas Prima Indonesia. Melalui publikasi tersebut diharapkan memberikan edukasi kepada masyarakat mengenai pertanggungjawaban pidana rumah sakit terhadap pemalsuan jumlah tagihan uang kepada BPJS 


\section{Metode Penelitian}

\begin{abstract}
Penelitian ini bersifat deskriptif analitis dimana peneliti akan menggambarkan permasalahan hukum yang berkaitan dengan perampasan aset milik pelaku tindak pidana korupsi yang telah dialihkan ke pihak ketiga. Pendekatan yang digunakan adalah pendekatan yuridis empiris, yaitu pendekatan dengan melihat dari segi yuridis (peraturan-peraturan atau norma-norma yang berlaku) yang didukung oleh pendekatan yuridis empiris (praktek penegakan hukum yang terjadi di lapangan).

Ditinjau dari data dan sumber data yang dibutuhkan dalam penelitian ini, maka penelitian ini tergolong penelitian lapangan karena peneliti terlibat langsung ke lapangan untuk mengumpulkan data yang dibutuhkan dalam penelitian.
\end{abstract}

\section{Hasil Penelitian}

Rumah sakit merupakan suatu institusi yang bergerak di bidang pelayanan kesehatan, yang sehari-hari melakukan kontak dengan pasien. Rumah sakit sebagai penyelenggara kesehatan dilakukan oleh jasa profesional yang pelayanannya dilakukan oleh dokter, perawat, dan tenaga ahli kesehatan lainnya, yang mempunyai tanggung jawab masing-masing. Tenaga kesehatan yang telah dipekerjakan oleh rumah sakit, harus sesuai dengan apa yang telah ditentukan oleh peraturan yang ada.

Rumah sakit dibagi berdasarkan pengelolaannya, dibagi menjadi rumah sakit publik dan rumah sakit privat. Rumah sakit publik dikelola oleh pemerintah, pemerintah daerah (provinsi dan kabupaten) ataupun yang dikelola oleh badan hukum yang bersifat nirbala, sehingga rumah sakit publik dapat disebut sebagai rumah sakit nonkomersial. Rumah sakit pemerintah diselenggarakan berdasarkan pengelolan Badan Layanan Umum atau Badan Layanan Daerah. Rumah sakit yang dikelola oleh pemerintah tidak dapat dialihkan menjadi rumah sakit privat yang diatur berdasarkan Pasal 20 Undang-Undang Rumah Sakit. Rumah sakit privat (swasta) dikelola oleh badan hukum dengan tujuan profit yang berbentuk Perseroan Terbatas atau Persero yang diatur Pasal 21 Undang-Undang Rumah Sakit, sehingga rumah sakit privat dapat sebagai rumah sakit yang komersial.

Rumah sakit diklasifikasikan berdasarkan fasilitas dan kemampuan pelayanannya, yaitu Rumah Sakit Umum dan Rumah Sakit Khusus. Rumah sakit umum yang terdiri atas Kelas A, Kelas B, Kelas C, dan Kelas D, sedangkan rumah 
sakit khusus terdiri dari Kelas A, Kelas B, Kelas C. Rumah sakit umum kelas A adalah rumah sakit yang mempunyai fasilitas dan kemampuan pelayanan medik paling sedikit 4 spesialis, 5 spesialis penunjang medic, 12 spesialis lain dan 13 subspesialis. Rumah sakit umum kelas B adalah rumah sakit umum yang mempunyai fasilitas dan kemampuan medik paling sedikit 4 spesialis, 4 spesialis penunjang medik, 8 spesialis dan 2 subspesialis dasar. Rumah sakit umum kelas $\mathrm{C}$ adalah rumah sakit umum yang mempunyai fasilitas dan kemampuan pelayanan medic paling sedikit 4 spesialis dasar dan 4 spesialis penunjang medik. Rumah sakit umum kelas D adalah rumah sakit umum yang mempunyai fasilitas dan kemampuan pelayanan medik paling sedikit 2 spesialis dasar.

Rumah sakit khusus kelas A adalah rumah sakit yang mempunyai fasilitas dan kemampuan paling sedikit pelayanan medik spesialis dan pelayanan medik subspesialis sesuai dengan kekhususan yang lengkap. Rumah sakit khusus B adalah rumah sakit khusus yang mempunyai fasilitas dan kemampuan paling sedikit pelayanan medik spesialis dan pelayanan medik subspesialis sesuai kekhususan yang terbatas. Rumah sakit khusus $\mathrm{C}$ adalah rumah sakit yang mempunyai fasilitas dan kemampuan paling sedikit pelayanan medik spesialis dan pelayanan medik spesialis sesuai dengan kehususan yang minimal.

Berdasarkan Pasal 20 UndangUndang Nomor 36 tahun 2009 tentang Kesehatan, negara telah menjamin kesehatan masyarakat dengan memberikan pelayanan kesehatan yang dijaminkan melalui Jaminan $\begin{array}{lll}\text { Kesehatan Nasional (JKN). JKN } & \end{array}$ diselenggarakan oleh Badan Penyelenggara Jaminan Sosial (BPJS). BPJS ditinjau dari pendirinya, didirikan oleh negara atau pemerintah melalui Undang-Undang Nomor 24 Tahun 2011 tentang BPJS. Kemudian ditinjau dari lingkup kerjanya, BPJS megatur hubungan negara dengan warga negara di bidang pelayanan umum, yang dalam hal ini adalah menyelenggarakan program jaminan sosial demi tercapainya kesejahteraan sosial.

Sejak Program Badan Penyelenggara Jaminan Sosial (BPJS) diberlakukan oleh Pemerintah, rumah sakit bekerja sama dengan BPJS dalam melayani pelayanan kesehatan pasien. Berdasarkan Pasal 23 Undang-Undang Nomor 40 Tahun 2004 tentang Sistem Jaminan Sosial Nasional, disebutkan bahwa jaminan kesehatan diberikan pada fasilitas kesehatan milik Pemerintah atau swasta yang menjalin 
kerjasama dengan BPJS. Fasilitas kesehatan meliputi rumah sakit, dokter praktik, klinik, laboratorium, apotek, dan fasilitas kesehatan lainnya.

Hubungan kerjasama antara BPJS dengan fasilitas kesehatan dilakukan dengan basis kontrak, yaitu perjanjian tertulis antara BPJS kesehatan dengan fasilitas kesehatan 3 yang terlibat. Salah satu yang harus dirumuskan secara jelas dalam kontrak adalah pokok transaksi, seperti pelayanan yang telah diberikan oleh fasilitas kesehatan untuk peserta program jaminan kesehatan, hak dan kewajiban dari masing-masing pihak, tata cara pelaksanaan hak dan kewajiban, masa berlakunya kontrak dan perpanjangannya, serta wanprestasi dan klausul lain yang umum terdapat dalam suatu kontrak. Dengan demikian, kontrak BPJS Kesehatan dengan fasilitas kesehatan harus dibuat dengan baik, agar saling menguntungkan bagi para pihak.

Dalam suatu riset yang dilakukan oleh beberapa dokter di Jerman terhadap negara-negara maju mengungkapkan bahwa kecurangan dalam perawatan kesehatan merupakan sumber yang paling potensial yang dapat merugikan perusahaan asuransi khususnya asuransi kesehatan. Kecurangan dilakukan dengan kesengajaan yang bermaksud untuk mendapatkan keuntungan atas perbuatan tersebut. Di Amerika Serikat industri asuransi kesehatan mengalami kerugian mencapai ratusan juta dolar dalam setahun yang ditimbulkan oleh perbuatan curang tersebut, yang apabila diestimasikan mengalami kerugian sekitar 3-7 \% ${ }^{3}$.

Masalah tersebut di atas menjadi menarik pada saat pemerintah Indonesia mencanangkan suatu reformasi kebijakan pembiayaan kesehatan dengan konsep Asuransi Sosial melalui Undang-Undang Nomor 40 Tahun 2004 tentang Sistem Jaminan Sosial Nasional (SJSN), saat pemerintahan Megawati akan segera berakhir. Komitmen memperluas jaminan sosial tersebut ditindak lanjuti oleh pemerintah dengan Presiden Susilo Bambang Yudoyono, melalui program asuransi kesehatan masyarakat miskin atau yang dikenal dengan ASKESKIN yang selanjutnya diganti dengan program Jaminan Kesehatan Masyarakat (Jamkesmas) dan berbagai program jaminan lainnya seperti Jaminan Masyarakat Daerah (Jamkesda)/Jaminan Masyarakat Kota (Jamkeskot) maupun Jaminan Persalinan ((Jampersal).

\footnotetext{
${ }^{3}$ Yohanes Budi Sarwo, Jurnal IImiah Hukum "Tinjauan Yuridis Terhadap Kecurangan (Frauds) Dalam Industri Asuransi Kesehatan Di Indonesia".
} 
Dalam periode tahun 2005-2006 pemerintah menganggarkan dana bagi hampir 60 juta penduduk miskin Indonesia, jumlah ini kemudian meningkat lagi menjadi untuk sekitar 76,4 juta jiwa penduduk miskin di tahun 2007. Dana yang disediakan diperuntukkan bagi pemberian pelayanan kesehatan primer di Puskesmas sampai ke tingkat lanjutan di Rumah Sakit, bahkan dapat digunakan untuk pelayanan yang sifatnya katastrofik (menghabiskan dana besar), seperti operasi, bedah caesar, cuci darah, hingga operasi jantung. Dana ini diserahkan pengelolaannya ke PT. Askes untuk kemudian dibayarkan ke Pemberi Pelayanan Kesehatan (PPK) dalam hal ini adalah rumah sakit. Perkembangan lebih lanjut pada saat ini pemerintah telah mengundangkan Undang-Undang Nomor 24 Tahun 2011 tentang Badan Penyelenggara Jaminan Sosial Nasional (BPJS). Di dalam BPJS tentang kesehatan telah diatur pelaksanaan jaminan kesehatan menggunakan sistem asuransi kesehatan sosial yang pada saat ini banyak menjadi pemberitaan yang cukup menarik.

$$
\text { Di dalam program asuransi }
$$
kesehatan komersial maupun sosial terdapat hubungan triparteit yaitu antara Perusahaan Asuransi/BPJS sebagai badan penyelenggara (Penanggung), Pengguna manfaat sebagai peserta (Tertanggung) dan Pemberi Pelayanan Kesehatan (PPK). Dalam pelaksanaan klaim asuransi sosial kesehatan tersebut sering terjadi kecurangan (fraud), hal ini pernah terjadi dalam program ASKESKIN dengan membengkaknya jumlah dana yang harus dibayarkan PT. Askes sebagai Penanggung ke Pemberi Pelayanan Kesehatan (PPK). Pada saat itu berbagai media sering ditulis keluhan PPK yang merasa haknya belum dibayar oleh PT. Askes, di sisi lain PT. Askes sebagai pihak pengelola dana merasa kewalahan membayar tagihan klaim yang ternyata jumlahnya melebihi kuota anggaran yang disediakan pemerintah, dan di sisi berikutnya ternyata pemerintah mengalami kesulitan mencari dana untuk menutupi kekurangan tersebut.

Dalam kondisi tersebut di atas, kemudian muncul berbagai pernyataan di media yang sepertinya menunjukkan sebuah kekalutan akibat kacaunya sistem pembiayaan yang diterapkan pada program ini. Dalam dalam bahasa Indonesia, terminologi fraud dalam asuransi dapat diartikan sebagai kecurangan.

Dalam kamus asuransi yang menjadi panduan bagi praktisi asuransi di Indonesia menyamakan pengertian fraud dengan tindak pidana penipuan, dan memberi 
pengertian fraud sebagai : "Tindakan penipuan, misrepresentatisi fakta penting yang dibuat secara sengaja, dengan maksud orang lain mempercayai fakta itu dan akibatnya orang itu menderita kesukaran keuangan "4. Berdasarkan beberapa definisi tersebut dapat dilihat bahwa fraud atau kecurangan memiliki empat kriteria yang harus dipenuhi, yaitu :

1) tindakan tersebut dilakukan oleh pelaku secara sengaja;

2) adanya korban;

3) korban menuruti kemauan pelaku;

4) adanya kerugian yang dialami oleh korban.

Berbagai bentuk kecurangan (fraud) serupa akan dapat mewarnai dalam klaim asuransi sosial kesehatan, yang dapat dilakukan oleh individu ataupun kelompok maupun oleh Pemberi Pelayanan Kesehatan pada tingkat pertama maupun rumah sakit sebagai penerima rujukan. Bentuk kecurangan ini dapat terjadi karena ketidak pahaman masyarakat pengguna pelayanan kesehatan ataupun dilakukan oleh PPK karena biaya pengobatan ditanggung oleh penanggung.

\footnotetext{
4 A. Hasymi Ali, Kamus Asuransi, cetakan II, PT Bumi Aksara,
} Jakarta, 2002, hlm.123.
Secara teoretis terdapat beberapa faktor penyebab yang memungkinkan terjadinya fraud, antara lain ${ }^{5}$ :

a. Kebutuhan (need) dimana situasi pemegang polis dan/atau tertanggung sebelum terjadinya kerugian sedang mengalami kesulitan keuangan.

b. Kesempatan (opportunity), misalnya sebab kerugian yang tidak dapat ditelusuri atau ada celah hukum yang dapat dimanfaatkan oleh pemegang polis dan/atau tertanggung untuk mengajukan klaim fiktif.

c. Keserakahan (greed) dapat tercermin dari rasionalisasi/sikap yang memandang tindakan fraud sebagai suatu pembenaran atau justifikasi dan sesuai dengan kode etik.

Dalam asuransi kesehatan terdapat berbagai kemungkinan yang dilakukan oleh berbagai pihak dalam melakukan pemalsuan ataupun kecurangan (fraud). Adapun berbagai kasus kecurangan yang pernah ditemukan oleh tim verifikasi Jamkesmas antara lain :

a. Kecurangan oleh Rumah Sakit/Laboratorium

\footnotetext{
${ }^{5}$ Department of Justice Health Care, Fraud Report Fiscal Year 1998, Washington, DC.
} 
1) Rumah sakit menambahkan tagihan klaim untuk pemeriksaan yang tidak pernah dilakukan;

2) Laboratorium menambah jenis pemeriksaan yang tidak diminta oleh dokter untuk tagihan klaimnya.

b. Kecurangan pelanggan obat

1) Menambah jumlah obat yang resepkan oleh dokter;

2) Mengganti obat generik dengan obat paten.

c. Kecurangan optical

1) Melakukan pemerikasan mata gratis dalam penggantian kaca mata namun dalam klaimnya terdapat biaya jasa pemeriksaan;

2) Memberikan discount harga kacamata yang sebenarnya harga telah dinaikan terlebih dahulu.

\section{d. Consumer fraud}

1) meminjamkan kartu kepada orang yang tidak berhak;

2) Menambahkan tagihan dalam kwitansi makanan suplemen atau bahan kosmetik;

3) Menggunakan pelayanan berlebihan misalnya membeli obat untuk selanjutnya dijual kembali.

\section{e. Application fraud}

Tertanggung bersama dengan agen asuransi menyembunyikan kondisi kesehatan dengan risiko tinggi

menjadi risiko rendah

f. Eligibility fraud

1) Bukan karyawan perusahaan/instansi mengaku karyawan;

2) Anggota keluarga diakui sebagai karyawan untuk mendapatkan pelayanan kesehatan;

3) Mantan karyawan masih ikut dalam daftar karyawan;

4) Mengikutkan sertakan dalam asuransi hanya untuk anggota keluarga yang berisiko sakitnya tinggi.

Kitab Undang-Undang Hukum Pidana (KUHP), mengatur mengenai Sumpah Palsu Dan Keterangan Palsu. Pasal 242 ayat:

(1) Barang siapa dalam keadaan di mana undang-undang menentukan supaya memberi keterangan di atas sumpah atau mengadakan akibat hukum kepada keterangan yang demikian, dengan sengaja memberi keterangan palsu di atas sumpah, baik dengan lisan atau tulisan, secara pribadi maupun oleh kuasanya yang khusus ditunjuk untuk itu, diancam dengan pidana penjara paling lama tujuh tahun.

(2) Jika keterangan palsu di atas sumpah diberikan dalam perkara pidana dan 
merugikan terdakwa atau tersangka, yang bersalah diancam dengan pidana penjara paling lama sembilan tahun.

(3) Disamakan dengan sumpah adalah janji atau penguatan yang diharuskan menurut aturan-aturan umum atau yang menjadi pengganti sumpah.

(4) Pidana pencabutan hak berdasarkan pasal 35 No. 1 - 4 dapat dijatuhkan.

KUHP, mengatur mengenai Pemalsuan Surat. Pasal 263 menyatakan pada ayat:

(1) Barangsiapa membuat surat palsu atau memalsukan surat yang dapat menimbulkan sesuatu hak, perikatan atau pembebasan hutang, atau yang diperuntukkan sebagai bukti daripada sesuatu hal dengan maksud untuk memakai atau menyuruh orang lain memakai surat tersebut seolah-olah isinya benar dan tidak dipalsu, diancam jika pemakaian tersebut dapat menimbulkan kerugian, karena pemalsuan surat, dengan pidana penjara paling lama enam tahun.

(2) Diancam dengan pidana yang sama, barang siapa dengan sengaja memakai surat palsu atau yang dipalsukan seolah-olah sejati, jika pemakaian surat itu dapat menimbulkan kerugian.

Tindak pidana pemalsuan surat yang dimaksudkan di dalam ketentuan pidana yang diatur dalam Pasal 263 ayat (1) KUHP terdiri atas unsur-unsur sebagai berikut:

a. Unsur subjektif : dengan maksud untuk menggunakannya sebagai surat yang asli dan tidak dipalsukan atau membuat orang lain menggunakan surat tersebut.

b. Unsur-unsur objektif: 1) barang siapa;2) membuat secara palsu atau memalsukan; 3)suatu surat yang dapat menimbulkan suatu hak, suatu perikatan atau suatu pembebasan utang atau; 4)suatu surat yang dimaksudkan untuk membuktikan suatu kenyataan; 5) penggunaannya dapat menimbulkan suatu kerugian.

Di dalam ketentuan pidana yang diatur dalam Pasal 263 ayat (1) KUHP tersebut pembentuk undang-undang ternyata tidak mensyaratkan keharusan adanya unsur kesengajaan atau unsur opzet pada diri pelaku, sehingga timbul pertanyaan apakah tindak pidana yang dimaksudkan di dalam ketentuan pidana yang diatur dalam Pasal 263 ayat (1) KUHP harus dilakukan dengan sengaja atau tidak.

KUHP, Pasal 264 ayat:

(1) Pemalsuan surat diancam dengan pidana penjara paling lama delapan tahun, jika dilakukan terhadap: 1. akta-akta otentik; 2. surat hutang atau sertifikat hutang dari sesuatu negara atau bagiannya ataupun dari 
suatu lembaga umum; 3. surat sero atau hutang atau sertifikat sero atau hutang dari suatu perkumpulan, yayasan, perseroan atau maskapai: 4. talon, tanda bukti dividen atau bunga dari salah satu surat yang diterangkan dalam 2 dan 3, atau tanda bukti yang dikeluarkan sebagai pengganti surat-surat itu; 5. surat kredit atau surat dagang yang diperuntukkan untuk diedarkan.

(2) Diancam dengan pidana yang sama barang siapa dengan sengaja memakai surat tersebut dalam ayat pertama, yang isinya tidak sejati atau yang dipalsukan seolah-olah benar dan tidak dipalsu, jika pemalsuan surat itu dapat menimbulkan kerugian.

Pasal 266 ayat:

(1) Barang siapa menyuruh memasukkan keterangan palsu ke dalam suatu akta otentik mengenai sesuatu hal yang kebenarannya harus dinyatakan oleh akta itu, dengan maksud untuk memakai atau menyuruh orang lain memakai akta itu seolah-olah keterangannya sesuai dengan kebenaran, diancam, jika pemakaian itu dapat menimbulkan kerugian, dengan pidana penjara paling lama tujuh tahun;

(2) Diancam dengan pidana yang sama barang siapa dengan sengaja memakai surat tersebut dalam ayat pertama, yang isinya tidak sejati atau yang dipalsukan seolah-olah benar dan tidak dipalsu, jika pemalsuan surat itu dapat menimbulkan kerugian.

Pasal 267 ayat:

(1) Seorang dokter yang dengan sengaja memberikan surat keterangan palsu tentang ada atau tidaknya penyakit, kelemahan atau cacat, diancam dengan pidana penjara paling lama empat tahun

(2) Jika keterangan diberikan dengan maksud untuk memasukkan seseorang ke dalam rumah sakit jiwa atau untuk menahannya di situ, dijatuhkan pidana penjara paling lama delapan tahun enam bulan.

(3) Diancam dengan pidana yang sama, barang siapa dengan sengaja memakai surat keterangan palsu itu seolah-olah isinya sesuai dengan kebenaran.

Pasal 268 ayat:

(1) Barang siapa membuat secara palsu atau memalsu surat keterangan dokter tentang ada atau tidak adanya penyakit, kelemahan atau cacat, dengan maksud untuk menyesatkan penguasa umum atau penanggung, diancam dengan pidana penjara paling lama empat tahun. (2) Diancam dengan pidana yang sama, barang siapa dengan maksud yang sama memakai surat keterangan yang tidak benar atau yang 
dipalsu, seolah-olah surat itu benar dan tidak dipalsu.

Pasal 269 ayat:

(1) Barang siapa membuat surat palsu atau memalsu surat keterangan tanda kelakuan baik, kecakapan, kemiskinan, kecacatan atau keadaan lain, dengan maksud untuk memakai atau menyuruh orang lain memakai surat itu supaya diterima dalam pekerjaan atau supaya menimbulkan kemurahan hati dan pertolongan, diancam dengan pidana penjara paling lama satu tahun empat bulan.

(2) Diancam dengan pidana yang sama barang siapa dengan sengaja memakai surat keterangan yang palsu atau yang dipalsukan tersebut dalam ayat pertama, seolah-olah surat itu sejati dan tidak dipalsukan.

Pasal 270 ayat:

(1) Barang siapa membuat surat palsu atau memalsukan pas jalan atau surat penggantinya, kartu keamanan, surat perintah jalan atau surat yang diberikan menurut ketentuan undang-undang tentang pemberian izin kepada orang asing untuk masuk dan menetap di Indonesia, ataupun barang siapa menyuruh beri surat serupa itu atas nama palsu atau nama kecil yang palsu atau dengan menunjuk pada keadaan palsu, dengan maksud untuk memakai atau menyuruh orang lain memakai surat itu seolah-olah sejati dan tidak dipalsukan atau seolah-olah isinya sesuai dengan kebenaran, diancam dengan pidana penjara paling lama dua tahun delapan bulan.

(2) Diancam dengan pidana yang sama, barang siapa dengan sengaja memakai surat yang tidak benar atau yang dipalsu tersebut dalam ayat pertama, seolah-olah benar dan tidak dipalsu atau seolah-olah isinya sesuai dengan kebenaran.

Pasal 271 ayat:

(1) Barang siapa membuat palsu atau memalsukan surat pengantar bagi kerbau atau sapi, atau menyuruh beri surat serupa itu atas nama palsu atau dengan menunjuk pada keadaan palsu, dengan maksud untuk memakai atau menyuruh orang lain memakai surat itu seolah-olah isinya sesuai dengan kebenaran, diancam dengan pidana penjara paling lama dua tahun delapan bulan.

(2) Diancam dengan pidana yang sama, barang siapa dengan sengaja memakai surat yang palsu atau yang dipalsukan tersebut dalam ayat pertama, seolaholah sejati dan tidak dipalsu atau seolah-olah isinya sesuai dengan kebenaran.

Pasal 274 ayat: 
(1) Barang siapa membuat palsu atau memalsukan surat keterangan seorang pejabat selaku penguasa yang sah, tentang hak milik atau hak lainnya atas sesuatu barang, dengan maksud untuk memudahkan penjualan atau penggadaiannya atau untuk menyesatkan pejabat kehakiman atau kepolisian tentang asalnya, diancam dengan pidana penjara paling lama dua tahun.

(2) Diancam dengan pidana yang sama, barang siapa dengan maksud tersebut, memakai surat keterangan itu seolaholah sejati dan tidak dipalsukan.

Pasal 275 ayat:

(1) Barang siapa menyimpan bahan atau benda yang diketahuinya bahwa diperuntukkan untuk melakukan salah satu kejahatan berdasarkan pasal 264 No. 2 - 5, diancam dengan pidana penjara paling lama sembilan bulan atau pidana denda paling banyak empat ribu lima ratus rupiah.

(2) Bahan-bahan dan benda-benda itu dirampas.

Pasal 276: Dalam hal pemidanaan berdasarkan salah satu kejahatan dalam pasal 263 - 268, dapat dijatuhkan pencabutan hak berdasarkan pasal 35 No. 1 4. Perbuatan pidana semata menunjuk pada perbuatan baik secara aktif maupun secara pasif, sedangkan apakah pelaku ketika melakukan perbuatan pidana patut dicela atau memiliki kesalahan, bukan merupakan wilayah perbuatan pidana, tetapi sudah masuk pada pertanggungjawaban pidana. Alat bukti ialah: segala apa yang menurut undangundang dapat dipakai untuk membuktikan sesuatu. Alat bukti; alat yang sudah ditentukan di dalam hukum formal yang dapat digunakan sebagai pembuktian di dalam acara persidangan, hal ini berarti bahwa di luar dari ketentuan tersebut tidak dapat dipergunakan sebagai alat bukti yang sah. Contoh: di dalam hukum pidana, secara formal diatur dalam Pasal 184 KUHAP. Alat bukti (Surat): segala sesuatu yang memuat tanda-tanda bacaan yang dimaksudkan untuk mencurahkan isi hati seseorang untuk pembuktian. Alat bukti surat; surat yang dibuat atas kekuatan sumpah jabatan atau dikuatkan dengan sumpah. Alat bukti tulisan: segala sesuatu yang memuat tandatanda bacaan yang bisa dimengerti dan mengandung suatu pikiran tertentu.

Disamping itu, dalam tatanan hukum Indonesia tindak pidana curang (fraud) terhadap perusahaan asuransi yang diatur oleh Kitab Undang-Undang Hukum Pidana (“KUHP”) dikategorikan dengan tindak pidana penipuan sebagaimana termaktub dalam Pasal 378 KUHP, Pasal 381 dan Pasal 382 KUHP. 
Di dalam Pasal 378 KUHP disebutkan : "Barang siapa dengan maksud untuk menguntungkan diri sendiri atau orang lain secara melawan hukum, dengan memakai nama palsu atau martabat palsu, dengan tipu muslihat, ataupun rangkaian kebohongan, menggerakkan orang lain untuk menyerahkan barang sesuatu kepadanya, atau supaya memberi hutang maupun menghapuskan piutang, diancam dengan penipuan dengan pidana penjara paling lama empat tahun"

Dalam ketentuan Pasal 381 KUHP disebutkan : "Barangsiapa dengan akal dan tipu muslihat menyesatkan orang menanggung asuransi tentang hal ikhwal yang berhubungan dengan tanggungan itu, sehingga ia menanggung asuransi itu membuat perjanjian yang tentu tidak akan dibuatnya atau tidak dibuatnya dengan syarat serupa itu, jika sekiranya diketahuinya keadaan hal ikhwal yang sebenarbenarnya, dihukum penjara selamalamanya satu tahun empat bulan".

Sedangkan dalam Pasal 382 KUHP disebutkan : "Barangsiapa dengan maksud akan menguntungkan diri sendiri atau orang lain dengan melawan hak, sedang hal itu merugikan yang menanggung asuransi atau orang yang dengan sah memegang surat penanggungan barang di kapal, membakar atau menyebabkan letusan dalam sesuatu barang yang masuk asuransi bahaya api, atau mengaramkan atau mendamparkan, membinasakan, atau merusakkan sehingga tanpa dapat dipakai lagi kapal (perahu) yang dipertanggungkan atas atau yang muatannya atau upah muatannya yang akan diterima telah dipertanggungkan atau yang untuk melengkapkan kapal (perahu) itu, orang sudah meminjamkan uang dengan tanggungan kapal (perahu) itu, dihukum penjara selama-lamanya lima tahun".

Berbagai kemungkinan kecurangan dalam bisnis asuransi tersebut di atas dapat dikategorikan dan telah memenuhi unsur tindak pidana kecurangan (fraud) yang dapat diancama dengan hukuman penjara selamalamanya satu tahun empat bulan. Di samping berbagai kasus kecurangan (fraud) tersebut di atas, dalam bisnis asuransi kesehatan juga sering terjadi berbagai pemalsuan. Adapun berbagai kasus pemalsuan yang sering terjadi adalah :

\section{a. Klaim palsu}

1) Dokter dalam melakukan klaim dalam bulan yang bersangkutan menggunakan sebagaian nama pasien yang datang berobat, sisanya hanya menggunakan kartu identitas tanpa pasien berobat; 
2) Beberapa nama pasien diajukan dengan beberapa kali kunjungan untuk berobat pada hal kenyataannya hanya berobat satu kali;

3) Beberapa nama keluarga pasien diajukan dalam klaim pada hal yang sebenarnya nama tersebut tidak berobat;

4) Unit Gawat Darurat (UGD) melakukan penagihan klaim tindakan yang sebenarnya tidak dilakukan.

b. Diagnose palsu

1) Kasus bedah kosmetik di klaim sebagai tindakan kasus kecelakaan;

2) Tertanggung mengajukan klaim untuk perawatan syaraf yang sebenarnya pada pasien dilakukan ekstrasi.

Berbagai kasus tindak pidana pemalsuan dalam bisnis asuransi tersebut di atas, bukan merupakan tindak pidana pemalsuan sebagaimana diatur dalam Pasal 21 (5) Undang-Undang Nomor 2 Tahun 1992 tentang Usaha Perasuransian, melainkan perbuatan pidana pemalsuan surat sebagaimana termaktub dalam Pasal 263 ayat (1) KUHP berbunyi sebagai berikut: "Barangsiapa membuat surat palsu atau memalsukan surat, yang dapat menerbitkan sesuatu hak, sesuatu perjanjian (kewajiban) atau sesuatu pembebasan utang, atau yang boleh dipergunakan sebagai keterangan bagi sesuatu perbuatan, dengan maksud akan menggunakan atau menyuruh orang lain menggunakan surat-surat itu seolah-olah surat itu asli dan tidak dipalsukan, maka kalau mempergunakannya dapat mendatangkan sesuatu kerugian dihukum karena pemalsuan surat, dengan hukuman penjara selamalamanya enam tahun."

Di dalam hukum pidana terdapat 2 (dua) unsur penting yang harus dipenuhi oleh pelaku perbuatan pidana pemalsuan adalah yaitu :

1) membuat surat palsu; yang dimaksud membuat surat palsu adalah membuat "surat" yang isinya bukan semestinya (tidak benar), atau membuat surat sedemikian rupa, sehingga menunjukkan asal surat itu yang tidak benar.

2) memalsukan surat. Tindakan memalsukan surat adalah mengubah surat demikian rupa, sehingga isinya menjadi lain dari isi yang asli atau sehingga surat itu menjadi lain dari pada yang asli. Memalsukan tandatangan adalah termasuk perbuatan pidana memalsukan surat, sedangkan yang diartikan sebagai surat dalam pasal ini adalah segala surat baik yang ditulis dengan tangan, dicetak, maupun ditulis memakai mesin tik dan lain-lainnya. Pemalsuan surat tersebut dapat 
menimbulkan keuntungan di satu pihak sekaligus kerugian bagi pihak lain. Suratsurat yang dipalsukan itu harus suatu-surat yang :

1) dapat menerbitkan suatu hak (misalnya: daftar tagihan rumah sakit (invoice) mengenai suatu jenis perawatan medis yang sebenarnya tidak pernah dilakukan)

2) dapat menerbitkan suatu perjanjian (misalnya: surat perjanjian asuransi)

3) dapat menerbitkan suatu pembebasan utang (misalnya: kwitansi) 4) suatu surat yang boleh dipergunakan sebagai suatu keterangan bagi sesuatu perbuatan atau peristiwa (misalnya: surat keterangan dokter)

Dalam beberapa kasus kejahatan asuransi, biasanya perbuatan pidana pemalsuan adalah perbuatan ikutan yang didahului oleh perbuatan pidana penipuan. Perbuatan pidana pemalsuan hanya sebagai pelengkap dari perbuatan pidana penipuannya, yang dapat diancam dengan hukuman penjara selama-lamanya enam tahun.

\section{Kesimpulan}

Berbagai bentuk kecurangan (fraud) serupa akan dapat mewarnai dalam klaim asuransi sosial kesehatan, yang dapat dilakukan oleh individu ataupun kelompok maupun oleh Pemberi Pelayanan Kesehatan pada tingkat pertama maupun rumah sakit sebagai penerima rujukan. Bentuk kecurangan ini dapat terjadi karena ketidak pahaman masyarakat pengguna pelayanan kesehatan ataupun dilakukan oleh PPK karena biaya pengobatan ditanggung oleh penanggung. Dalam beberapa kasus kejahatan asuransi, biasanya perbuatan pidana pemalsuan adalah perbuatan ikutan yang didahului oleh perbuatan pidana penipuan. Perbuatan pidana pemalsuan hanya sebagai pelengkap dari perbuatan pidana penipuannya, yang dapat diancam dengan hukuman penjara selama-lamanya enam tahun. 


\section{DAFTAR PUSTAKA}

\section{Buku dan Jurnal}

A. Hasymi Ali, Kamus Asuransi, cetakan II, PT Bumi Aksara, Jakarta, 2002.

Kanon Armiyanto, makalah Seminar Sehari "Kecurangan (fraud) Dalam Jaminan/Asuransi Kesehatan" diselenggarakan oleh PAMJAKI (perhimpunan Ahli Manajemen Jaminan dan Asuransi Kesehatan Indonesia) di Hotel Bumi Karsa, pada tanggal 13 Desember 2007.

Yohanes Budi Sarwo, Jurnal Ilmiah Hukum "Tinjauan Yuridis Terhadap Kecurangan (Frauds) Dalam Industri Asuransi Kesehatan Di Indonesia”.

Department of Justice Health Care, Fraud Report Fiscal Year 1998, Washington, DC.

\section{Peraturan Perundang-undangan}

Undang-Undang Dasar Negara Republik Indonesia Tahun 1945 (UUD 1945), tepatnya di dalam alinea ke-4 Pembukaan UUD 1945, dengan menempatkan frase memajukan kesejahteraan umum e sebagai salah satu cita negara Republik Indonesia.

Undang-undang Nomor 3 Tahun 1971 Tentang Pemberantasan Tindak Pidana Korupsi.

Undang-Undang No. 40 Tahun 2004 Tentang Jaminan Sosial Nasional.

Undang-Undang No. 44 Tahun 2009 Tentang Rumah Sakit.

Undang-Undang No. 24 Tahun 2011 Tentang Badan Penyelenggara Jaminan Sosial. Kitab Undang-Undang Hukum Pidana. 